Centro de Estudios Constitucionales de Chile Universidad de Talca

"La soberanía, el poder constituyente y una nueva Constitución para Chile"

Lautaro Ríos Álvarez

\title{
LA SOBERANÍA, EL PODER CONSTITUYENTE Y UNA NUEVA CONSTITUCIÓN PARA CHILE*
}

Sovereignty, CONSTituent POWER AND A New Chilean Constitution

LAUTARo Ríos Álvarez ${ }^{1}$

lautarorios@estudiorios.cl

RESUMEN: Este trabajo pretende abordar el concepto de soberania y sus diversas clasificaciones, desde una perspectiva tanto diacrónica como sincrónica. Del mismo modo, se examina el concepto de poder constituyente. Finalmente se aplican estos conceptos a los intentos recientes en Chile de discutir una nueva Constitución. El artículo afirma que la mejor manera de ser fiel al concepto de soberanía es recurriendo al mecanismo de la asamblea constituyente.

PALABRAS CLAVE: Soberanía; poder constituyente, poder instituido, democracia. Constitución chilena, asamblea constituyente.

ABSTRACT: This paper aims at analyzing the concept of sovereignty and various classifications, from a diachronic and synchronic standpoint. Likewise, the concept of constituting power is also addressed. Lastly, this paper applies those concepts to the very recent intents to discuss a new constitution in Chile. This work argues that the best way to fully abide by the concept of sovereignty in Chile is using the mechanism of a constituent assembly.

KEYWORDS: Sovereignty, constituent power, instituted power, democracy, Chilean constitution, constituent assembly.

\section{INTRODUCCIÓN}

Estamos en los albores de una etapa decisiva en nuestra evolución política.

Después de un desarrollo lento, pero progresivo, de nuestra vida republicana durante un poco más de siglo y medio de historia cívica (1818-1973), caímos en un foso del que tardamos diecisiete años en salir y de cuyas consecuencias aún no hemos logrado recuperarnos.

La República democrática se derrumbó en Chile el 11 de septiembre de 1973. El bombardeo del Palacio de Gobierno constituyó un acto emblemático. El país

\footnotetext{
* Ponencia presentada en las XLIV Jornadas Chilenas de Derecho Público, celebradas en la P.U.C.CH. el 6 y 7 de octubre de 2014.

1 Abogado. Magíster en Derecho. Doctor en Derecho. Profesor Emérito de Derecho Constitucional y Político de la Escuela de Derecho de la Universidad de Valparaíso. E-mail: lautarorios@estudiorios.cl.
} 
quedó dividido entre amigos y enemigos del gobierno militar. Quienes no eran sus adictos fueron mirados como sus adversarios. Para éstos, se suspendieron las garantías de los derechos humanos. Comenzaron las detenciones arbitrarias, las torturas denigrantes y la macabra historia de los detenidos desaparecidos que aún no termina de esclarecerse. En la oportunidad debida, denunciamos la práctica del exilio como una acción ilegítima e inmoral; rechazamos la destrucción de la institucionalidad chilena y del tejido social laboriosamente construidos con el esfuerzo de todos; condenamos el oprobio antijurídico del art. $8^{\circ}$ original de la Carta de 1980 y la incongruencia con ella misma de la Disposición Transitoria 24a. de su texto primitivo. También denunciamos la ilegitimidad de dicha Constitución ${ }^{2}$.

Aunque todavía hay quienes viven la fantasía de creer que estamos regidos por una Constitución legítima, resulta evidente para nosotros que se trata de una Carta Fundamental espuria, originada a raíz de un acto sedicioso -el golpe militar de 1973- y, por ende, un acto delictivo; precedido de un proceso transgresor de las normas establecidas para reformar la Constitución de 1925, vigente en esa fecha; elaborada por dos órganos designados a dedo por la Junta Militar detentadora del poder; aprobada ilegítimamente por ella misma bajo el designio de establecer en Chile una "democracia protegida" por el estamento castrense; y-para coronar esta comedia de equivocaciones- sometida a un "plebiscito" desprovisto de todo control jurídico y político, cuyo resultado estaba asegurado de antemano.

La etapa de apertura de nuestra conciencia política que estamos viviendo, está marcada por varios signos premonitorios. Si bien nos liberamos -a partir de la reforma constitucional del año 2005- de la tutela militar impuesta sobre diversas instituciones políticas, seguimos sintiendo la camisa de fuerza constituida por los enclaves autoritarios subsistentes que limitan y a veces impiden el ejercicio democrático del poder.

Las leyes orgánicas constitucionales -dictadas casi en su totalidad durante el gobierno militar- mantienen inmovilizado el régimen político, comenzando con el sistema electoral.

Los derechos sociales -que son tan fundamentales como el resto de los que gozan de rango constitucional- no han podido abrirse camino en su ejercicio efectivo por el sector más vulnerable de nuestra población.

En materia de relaciones internacionales vivimos como un país insular y ni siquiera sabemos expresar el anhelo de la unidad latinoamericana que está inscrito

2 Pontificia Universidad Católica de Chile: "Razón y Fuerza de la Constitución de 1980" en XIX Jornadas Chilenas de Derecho Público, pp. 325 y ss. 
y late con fuerza en la casi totalidad de las Cartas Constitucionales de nuestros países hermanos y que constituye una herramienta fundamental para emerger -unidos- de nuestro subdesarrollo endémico.

Pese a todo, se respira en la conciencia colectiva la necesidad de incorporar estas aspiraciones en una nueva y legítima Constitución nacida de la voluntad del pueblo. Y es importante destacar que el Gobierno de Chile ha expresado en su Programa su intención de encabezar esta iniciativa.

Todas estas razones nos mueven a colaborar, con nuestro modesto aporte, a convertir este sueño en realidad.

\section{Primera Parte: La soberanía}

\section{IDEA HISTÓRICA DE LA SOBERANÍA}

Si bien existe consenso en la doctrina acerca de que el concepto de soberanía -su análisis, definición y caracteres- es obra del abogado, filósofo y economista francés Jean Bodin (o Juan Bodino en su versión española) en su opera prima: Los Seis Libros de la República, editado en francés en la casa Du Puys de París, en 1575, también existe el convencimiento de que la soberanía es un fenómeno histórico-político presente desde la más remota antigüedad en toda sociedad evolucionada hasta convertirse en Estado.

Así, se ejerció soberanía en los Estados teocráticos existentes en la India, en el antiguo Egipto, en China y en la descripción bíblica del Estado hebreo; en los estudios de Aristóteles sobre la polis griega y sus diversas Constituciones y en las versiones monárquica, republicana e imperial de la antigua Roma.

También existió soberanía en los Estados conformados por los pueblos ancestrales de América. Así lo sugieren los vestigios de la cultura Maya y la de Tiahuanaco, así como la historia de los imperios Inca y Azteca ${ }^{3}$, ambas civilizaciones peatonales; no obstante lo cual dejaron impresionantes huellas de su organización política, de su estructura administrativa, de su estadística, de su maestría en la urbanización de sus ciudades, sus carreteras, sus técnicas de regadío, sus sistemas de comunicación y sus obras monumentales que dejaron asombrados a los

3 El pueblo "azteca" nunca existió. Aztlán era una ciudad mítica, hecha de oro,buscada por los españoles cuando llegaron a Tenochtitlán, creyendo haber descubierto Aztlán. De allí la expresión "azteca”, habitante de Aztlán. 
conquistadores españoles, a su llegada a estas tierras, por su estado de adelanto superior, a veces, al de Europa ${ }^{4}$.

A menudo los cultores de la Ciencia Política se detienen a analizar el origen atribuido en las distintas culturas al poder supremo. En las más antiguas culturas todo poder provenía de Dios, quien, a veces, lo ejercía directamente como habría ocurrido en la liberación del pueblo hebreo de la oprobiosa servidumbre que le impuso el faraón egipcio, mediante las conocidas plagas con que Jehová castigó al propio faraón y a su pueblo5.

En otras culturas -como ocurrió en el antiguo imperio egipcio, entre los Incas y los Tenochcas- el gobernante era considerado una personificación de Dios, por lo que ejercía la soberanía sin limitación alguna sobre sus súbditos, sus vidas y sus bienes.

De parecido poder gozaban los reyes en las monarquías absolutas en consideración al supuesto origen divino de la soberanía de la cual eran depositarios, siendo - por lo mismo- responsables de su ejercicio sólo ante Dios.

Toda esta construcción monolítica e ilimitada del poder político se derrumbó al cambiar el centro de gravedad de la titularidad de la soberanía, radicándose en el pueblo, en la Constitución de los Estados Unidos de Norteamérica de 1787 ("We, the people ..."); o en la nación, en la Declaración de los Derechos del Hombre y del Ciudadano, de los representantes del pueblo francés, de $1789^{6}$.

\section{CONCEPTO DE LA SOBERANÍA EN LA}

DOCTRINA Y EN LAS CONSTITUCIONES MODERNAS

\subsection{La soberanía en la doctrina}

Bodin calificó la soberanía como "La suprema autoridad" y la definió como "el poder absoluto y perpetuo de una República". Y añadió que "Los latinos la llaman maiestate, ... los italianos señoría...; los hebreos la dice scient musar, es decir, la mayor autoridad de mandar. $Y$ asi es necesario fundar en esto la definición de suprema

\footnotetext{
4 BAUDIN

5 Biblia: Éxodo, Capítulos 7 al 12.

6 Su art. 3 reza: "Le principe de toute Souveraineté réside essentiellement dans la nation. Nul corps, nul individu ne peut exercer d'autorité qui n'en émane expressément".
} 
autoridad, por no haber jurisconsulto ni filósofo político que la haya definido, con ser punto muy necesario cuando se trata del Estado o de la República" 7.

Cuatro siglos después de Bodin, un hijo del fallecido catedrático español Nicolás Pérez Serrano, publicó su obra póstuma, el Tratado de Derecho Político, que dedica varios capítulos al estudio de "El Poder del Estado. La Soberanía" -incluyendo una valiosa sinopsis histórica de esta institución- en que advierte que "Hoy (1976) puede afirmarse que el Estado y la soberanía son los dos temas capitales del Derecho Político, si no es que ambos constituyen un mismo problema, porque no se explica el concepto del Estado sin el de la soberanía, ni ésta puede predicarse más que de comunidades politicas que ostentan la categoría estatal".

Resulta curioso que una mente tan esclarecida como la de Pérez Serrano, al referirse a "El concepto de soberanía", omita dar su propia definición y, en cambio, se remita a otros dos autores: Francisco Giner de los Ríos y Herman Heller.

El primero expresó que la soberanía consiste en "el poder supremo del Estado para hacer que el Derecho reine en la sociedad".

El segundo definió la soberanía como "aquella propiedad que implica absoluta independencia de una unidad de voluntad con respecto a otra unidad de decisión de carácter universal y efectivo; y en sentido positivo decimos que aquella unidad de voluntad es la más alta unidad decisoria universal en aquel orden concreto de imperium" 8 .

Agrega Heller que "El poder del Estado, considerado desde un punto de vista existencial y en la relación con otros poderes que se encuentran en su territorio, es un poder superior porque está sobre ellos, del mismo modo que una organización económica puede ser superior a otra. Pero es el poder supremo como sujeto de la soberanía, porque está supraordinado a todos los restantes poderes dentro de su territorio y dicta las normas jurídicas supremas. Según esto, la soberanía del Estado no es más que la consecuencia necesaria de su función social. El poder del Estado tiene que ser, desde el punto de vista del derecho, el poder político supremo, y desde el punto de vista del poder, el poder político normalmente más fuerte, dentro de su territorio, pues de lo contrario no será soberano ni poder del Estado" ".

Thomas Hobbes había sostenido lo siguiente: la esencia del Estado se puede definir así: "Una persona de cuyos actos una gran multitud, por pactos mutuos, rea-

7 Bodin, p. 267.

8 Pérez (1976), Cap. VIII: pp. 119-131; y “Sinopsis Histórica de la Soberanía”: Cap. IX y X: pp. 133 a 169.

9 Heller (1983), p. 265. 
lizados entre si, ha sido instituida por cada uno como autor, al objeto de que pueda utilizar la fortaleza y medios de todos, como lo juzgue oportuno, para asegurar la paz $y$ defensa común. El titular de esta persona se denomina soberano, y se dice que tiene poder soberano; cada uno de los que le rodean es súbdito suyo" 10.

Fischbach definió la soberanía como sigue: "Soberanía es la capacidad ilimitada del Estado para su autodeterminación jurídica.

"El desenvolvimiento histórico del concepto de soberanía es en general paralelo al del concepto de Estado. Como consecuencia de este desenvolvimiento, hemos deducido que soberanía significa independencia del Estado de toda subordinación a cualquier poder extraño, y en cuanto a lo interior, poder supremo. Como tercera nota de la soberania se ha señalado también la ilimitabilidad absoluta, esto es, la imposibilidad de oponerle límites jurídicos por considerar que no admite más que los reales y morales"1 1 .

Georg Jellinek sostuvo que "La evolución histórica de la soberanía nos demuestra que ésta significó la negación de toda subordinación o limitación del Estado por cualquier otro poder. Poder soberano de un Estado es, por tanto, aquel que no reconoce ningún otro superior a si; es, por consiguiente, el poder supremo e independiente".

Y agrega más adelante: "Pero la doctrina de la soberanía tiene una tercera nota derivada del carácter de la soberanía misma. Ella debe designar un poder ilimitado e ilimitable que habría de ser absoluto, ya que nadie podría limitarlo, ni aun siquiera ella misma" 12 .

Hans Kelsen, refiriéndose a la soberanía, señala que "El poder del Estado suele mencionarse como el tercero de los llamados 'elementos' de éste. El Estado es concebido como un agregado de individuos, es decir, como un pueblo que vive dentro de una parte limitada de la superficie de la tierra, y se encuentra sujeto a un determinado poder: un Estado, un territorio, una población y un poder. Afirmase que la soberanía es la característica que define a ese poder".

Y luego, añade: 'La palabra 'poder' tiene diferentes significaciones, de acuerdo con esos distintos usos. El poder del Estado a que el pueblo se encuentra sujeto, no es sino la validez y eficacia del orden jurídico, de cuya unidad deriva la del territorio y la del pueblo. El 'poder' del Estado tiene que ser la validez y eficacia del orden jurídico nacional, si la soberania ha de considerarse como una cualidad de tal poder. Pues la soberanía unicamente puede ser la cualidad de un orden normativo, considerado

\footnotetext{
10 Hobbes (1980), p. 141.

11 FischBACH: pp. 81 y 83-84.

12 Jellinek (1978), pp. 356-357.
} 
como autoridad de la que emanan los diversos derechos y obligaciones. Cuando, por otra parte, se habla de los tres poderes del Estado, la palabra 'poder' es entendida en el sentido de una función del Estado, y entonces se admite la existencia de funciones estatales distintas"13.

Carré de Malberg, en su Teoría General del Estado (Francia, 1922), al referirse a las teorías contemporáneas sobre el origen del poder -y luego de denunciar los errores de la teoría del derecho divino de los reyes fundada en San Pablo: "Omnia potestas a Deo”- hace un interesante análisis de las teorías de la soberanía popular y de la soberanía nacional, a partir de la Revolución Francesa.

Respecto de la primera, sostiene que "En el momento actual, la teoría más extendida, respecto a la cuestión de la residencia ordinaria de la soberanía, es aquella que sitúa la fuente del poder en el pueblo, en la masa común de los ciudadanos. Esta idea debe su fuerza de expansión al desarrollo de la civilización democrática, y también se la debe a los continuos progresos del espíritu individualista, por más que, llevada a sus consecuencias extremas, pueda llegar a ser excesivamente opresora para el individuo, al menos en aquellos pueblos que sólo poseen en grado insuficiente el sentido de la justicia y de la libertad. Pero, además, debe su éxito, especialmente en Francia, a la seducción de las fórmulas que dio de ella su principal propagador, Juan Jacobo Rousseau.

No es que la haya descubierto Rousseau, ni que la haya expuesto por vez primera. Sin referirnos a los teólogos, que desde la Edad Media situaban la residencia de la potestad soberana en la comunidad popular, ni a las tentativas hechas en los Estados Generales de 1355, y sobre todo en los de 1484, con objeto de lograr la admisión de esta misma idea, ni finalmente a la tesis, muy absoluta, sostenida en el mismo sentido en el siglo XVI por los monarcómacos, basta recordar que, ya antes de Rousseau, habia fundado Hobbes su teoría del absolutismo del principe en la afirmación de que la masa de los ciudadanos transfería al rey la potestad que se hallaba originariamente en ella: que Jurieu, al proclamar la necesidad de una 'autoridad que no haya de tener razón para convalidar sus actos', había añadido que 'esta autoridad tan sólo se encuentra en el pueblo; que Locke fundó igualmente la sociedad civil y su potestad en el consentimiento de sus miembros (Esmein, Éléments, 7a. ed., vol. I, pp. 278 ss., 285 ss., 291 ss.; Duguit, Traité, vol. I, pp. 29 ss.). Pero fue Rousseau quien dio a esa doctrina su expresión teórica más clara, particularmente en su Contrato Social,

13 Kelsen, Hans. Teoría General del Derecho y del Estado, UNAM, México, 1983, p. 302. 
y además, quien dedujo sus consecuencias prácticas con una precisión y una valentía que no alcanzó ninguno de sus predecesores".

Respecto de la soberanía nacional, explica que "Según el derecho positivo francés, a la teoría de la soberanía del pueblo debe oponerse el sistema de la soberanía nacional.

El concepto de soberanía nacional es en Francia uno de los principios fundamentales del derecho público y de la organización de los poderes.

Se ha dicho de este principio que es la más importante de las conquistas realizadas por la Revolución. De hecho fue consagrado, desde el principio de los acontecimientos de 1789, por la Declaración de los derechos del hombre y del ciudadano, art. 3: 'El principio de toda soberanía reside esencialmente en la nación. Ningún cuerpo, ningún individuo puede ejercer autoridad que no emane de ella expresamente. Desde entonces, y salvo una sola interrupción en 1814, la soberanía nacional, al menos en teoría, ha sido admitida explícita o implícitamente por las sucesivas Constituciones de Francia. Fue en primer lugar la Constitución de 1791 la que, en los arts. $1^{\circ}$ y $2^{\circ}$ del preámbulo de su tít. III, declaró que la soberanía pertenece a la nación... de la que emanan todos los poderes'. Según el art. 25 de la Declaración de derechos que encabeza la Constitución de 1793, 'la soberania reside en el pueblo'. La Constitución del año III (art. 17 de su Declaración de derechos) dice que 'reside en la universalidad de los ciudadanos. En la Constitución del año VIII y durante el Imperio, la soberania nacional se afirma bajo forma plebiscitaria. En 1814 ya no se trata de la soberania de la nación: en el sistema de la Carta, la soberanía, como en la antigua monarquí, reside en la persona del rey. Pero, a partir de 1830, el principio de la soberanía nacional vuelve a estar en vigor; y desde esta época se ha mantenido en 1848, en 1852 y en el derecho público actual. La Constitución de 1848 lo proclama aún de una manera expresa en su art. $1^{\circ}$. La de 1852 (art. 10) declara que 'reconoce, confirma y garantiza los grandes principios proclamados en 1789'. Y si hoy día no se encuentra ninguna fórmula especial, a este respecto, en la Constitución tan lacónica de 1875, los autores no dejan de estar de acuerdo en decir que toda la organización constitucional actualmente existente se basa en la idea de la soberanía nacional"14.

Felice Battaglia apunta que: "cuando se dice que el Estado es el centro de un ordenamiento jurídico, no sólo en el sentido de que de él irradian las variadas normas que constituyen el ordenamiento, sino además en el de que las normas se encuadran en él, se quiere entonces decir que el Estado en cuanto tal es el sujeto de aquel ordenamiento, que impone este ordenamiento y que es una voluntad posible (la realidad

14 Carré de Malberge (2000), pp. 875 y ss. 
aqui no entra en juego) que sostiene dicho ordenamiento. $Y$ si el Estado es sujeto de derecho, la soberanía es su capacidad".

Y agrega: "Así como la capacidad es la plenitud de la subjetividad jurídica del hombre fisico, asi la soberania es la plenitud de la subjetividad jurídica del Estado, y está vinculada, pues, a la configuración de su personalidad en el orden jurídico. Aparece, por tanto, la soberanía ligada a la personalidad, tan intimamente que las dos nociones parecen una sola, en modo tal que o se defienden juntas o juntas decaen"15.

André Hauriou, al referirse a la soberanía, la explica así:

"La soberanía del Estado. Es tradicional la afirmación de que el Estado posee la soberanía.

Esta noción de la soberanía del Estado es una noción compleja, dado que puede enfocarse desde el plano del Derecho interno y desde el plano del Derecho internacional. $Y$ también porque ha evolucionado con el tiempo y se presentó inicialmente con un carácter puramente politico para transformarse progresivamente en una noción jurídica.

La Concepción Politica de la Soberanía del Estado. Esta concepción, creada principalmente por Bodino en los Seis libros de la República, publicados en 1576, establece una equivalencia entre soberanía e independencia absoluta.

Consiste en afirmar que el Estado está libre de todo tipo de subordinación frente a cualquier otro poder y, en gran medida, es visible en ella la impronta de la época en que se formuló. En efecto, en el siglo XVI y principalmente en el reino de Francia, se trataba de afirmar la supremacía del rey sobre los grandes feudatarios así como la independencia de la Corona frente a la Santa Sede y al Sacro Imperio Romano Germánico. Esta independencia de Francia frente a todo poder extranjero se afirma en dos sentencias o máximas heredadas de los juristas:

El rey recibe su corona únicamente de Dios.

El rey es emperador en su reino.

Aunque haya sido puesta a punto especialmente para responder a una necesidad momentánea, la concepción de la soberanía-independencia fue en gran parte conservada por el Derecho internacional. Está en la base de la doctrina de la independencia de los Estados y justifica el principio de no intervención. Explica también que los Estados sólo voluntariamente se someten a arbitrajes o a procedimientos de justicia internacional.

Pero esta concepción de la soberania-independencia tiene el defecto de ser absoluta $y$ también el de tener un carácter negativo, sin darnos ninguna indicación sobre el

15 Battaglia (1966), pp. 128-129. 
contenido de este poder del Estado. Ha sido sustituida progresivamente por una concepción jurídica, más flexible y más explicativa"16.

García Cotarelo afirma que: "En un sentido operativo (...) la soberanía sería sustancialmente el reconocimiento de la necesidad de independencia del Estado frente a poderes exteriores y de superimposición sobre factores internos, elementos ambos requeridos para hacer eficaz y continuada la acción del Estado"17.

De Jouvenel describe la soberanía como: "una voluntad suprema que ordena y rige la comunidad humana, una buena voluntad por naturaleza y a la cual resulta ilícito oponerse, una buena voluntad divina o voluntad general'18.

González Casanova afirma por su parte: "La nación no necesita del Estado para llegar a ser. La nación se crea ella sola a si misma, pues consiste en la unión política de la gente. Por el contrario, la unidad de voluntad común, rasgo axial de la nación, le permite formar un todo que quiere y actúa. Si lo propio de la soberanía era la unidad de decisión suprema y, en la sociedad estamental, como en la individualista, esa unidad sólo la podía aportar el monarca, aunque se disfrazara, como Hobbes, de Leviatán, y, con Kant, de Derecho, ahora tenemos ya al nuevo sujeto de la soberanía. La soberanía o poder politico supremo reside en la Nación en cuanto es un todo que quiere y actúa originariamente"19.

Algunos de los autores citados -notoriamente, Kelsen, Carré de Malberg y Battaglia- reducen la soberanía a su dimensión puramente jurídica, propia de un orden normativo, despojándola de su naturaleza política, de su origen histórico y de su fundamento filosófico, a los que consideran enfoques metajurídicos, propios de otras disciplinas.

Nosotros pensamos que el contexto histórico y sociológico en que nacen las instituciones jurídicas, así como sus fundamentos teóricos, las impregnan de su contenido de tal modo que su resultado normativo no puede prescindir de ellas sin desfigurar su identidad.

Para los efectos de este trabajo, entendemos por soberanía el poder supremo del Estado para organizarse como tal, dictar y modificar su Constitución Política, dirigir su desarrollo interno y sus relaciones con los demás Estados y organizaciones internacionales y proteger la existencia y los derechos de su población, la

16 Hauriou et al. (1980), pp. 168-169.

17 García (1983), pp. 110 y 111.

18 De Jouvenel (1964), p. 36.

19 GonZÁlez (1983), p. 119. 
integridad de su territorio y la autonomía del ejercicio de sus poderes, sin hallarse sometido a ningún poder extraño.

La soberanía sigue siendo el poder originario y supremo del Estado; es una e indivisible en su esencia y titularidad, aunque el ejercicio de sus funciones esenciales sea susceptible de repartirse en distintos órganos; es permanente porque su existencia es consustancial a la existencia del Estado. Finalmente, como elemento constitutivo del Estado, la soberanía es indelegable, sin perjuicio de que el Estado pueda encomendar -conforme a la Constitución- el ejercicio de alguna parte de sus funciones a órganos distintos a los establecidos en ella.

\subsection{La soberanía en las Constituciones modernas}

A efectos de verificar la fuente en la cual radica la soberanía de las Constituciones posteriores a la Segunda Guerra Mundial, transcribiremos los preceptos respectivos de las Cartas Fundamentales más significativas de América, Europa y de otros continentes.

Constituciones americanas

\section{Constitución Política de la República de Chile de 1980. Art. 5:}

"La soberanía reside esencialmente en la Nación. Su ejercicio se realiza por el pueblo a través del plebiscito y de elecciones periódicas y, también, por las autoridades que esta Constitución establece. Ningún sector del pueblo ni individuo alguno puede atribuirse su ejercicio.

El ejercicio de la soberanía reconoce como limitación el respeto a los derechos esenciales que emanan de la naturaleza humana. Es deber de los órganos del Estado respetar y promover tales derechos, garantizados por esta Constitución, asi como por los tratados internacionales ratificados por Chile y que se encuentren vigentes".

Constitución de la República Federativa de Brasil de 1988. Art. 1:

"Parágrafo único. Todo el poder emana del pueblo, que lo ejerce por medio de representantes elegidos directamente, en los términos de esta Constitución”.

Constitución de Colombia de 1991. Art. $3^{\circ}$ :

"La soberanía reside exclusivamente en el pueblo, del cual emana el poder público. El pueblo la ejerce en forma directa o por medio de sus representantes, en los términos que la Constitución establece".

Constitución del Perú de 1993. Art. 45:

"El poder del Estado emana del pueblo. Quienes lo ejercen lo hacen con las limitaciones y responsabilidades que la Constitución y las leyes establecen. 
Ninguna persona, organización, Fuerza Armada, Policía Nacional o sector de la población puede arrogarse el ejercicio de ese poder. Hacerlo constituye rebelión o sedición".

Constitución de Venezuela de 1999. Art. 5:

"La soberanía reside intransferiblemente en el pueblo, quien la ejerce directamente en la forma prevista en esta Constitución y en la ley, e indirectamente, mediante el sufragio, por los órganos que ejercen el Poder Público.

Los órganos del Estado emanan de la soberanía popular y a ella están sometidos".

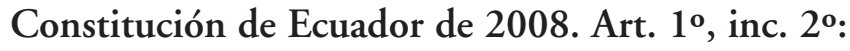

"La soberanía radica en el pueblo, cuya voluntad es el fundamento de la autoridad, y se ejerce a través de los órganos del poder público y de las formas de participación directa previstas en la Constitución".

Constitución de Bolivia de 2008. Art. $7^{\text {o: }}$

"La soberania reside en el pueblo boliviano, se ejerce de forma directa y delegada. De ella emanan, por delegación, las funciones y atribuciones de los órganos del poder público; es inalienable e imprescriptible".

Constitución de Nicaragua de 2014. Art. $2^{\circ}$ :

"La soberanía nacional reside en el pueblo y la ejerce a través de instrumentos democráticos decidiendo y participando libremente en la construcción y perfeccionamiento del sistema económico, político, cultural y social de la nación. El poder soberano lo ejerce el pueblo por medio de sus representantes libremente elegidos por sufragio universal, igual, directo y secreto, sin que ninguna otra persona o reunión de personas pueda arrogarse esta representación. También lo puede ejercer de forma directa a través del referéndum y el plebiscito.

Asimismo, podrá ejercerlo a través de otros mecanismos directos, como los presupuestos participativos, las iniciativas ciudadanas, los Consejos territoriales, las asambleas territoriales y comunales de los pueblos originarios y afrodescendientes, los Consejos sectoriales, y otros procedimientos que se establezcan en la presente Constitución y las leyes".

\section{Constituciones europeas.}

Constitución de la República Federal de Alemania de 1949. Art. 20.2:

"Todo el poder estatal emana del pueblo (Alle Staatsgewalt geht vom Volke aus), el cual lo ejerce en las elecciones y votaciones y mediante los órganos legislativos, ejecutivos y judiciales".

Constitución de la República de Francia de 1958. Art. 30:

"La soberanía nacional pertenece al pueblo, que la ejercerá a través de sus representantes y por vía de referéndum. 
Ninguna sección del pueblo y ningún individuo podrán arrogarse el ejercicio de la soberanía".

Constitución de Portugal de 1976. Art. 3.1.:

"La soberanía, una e indivisible, reside en el pueblo, que la ejerce conforme a las modalidades previstas en la Constitución".

Constitución de España de 1978. Art. 1.2.:

"La soberanía nacional reside en el pueblo español, del que emanan los poderes del Estado".

Constitución de Croacia de 1990. Art. 1:

La República de Croacia es un Estado democrático y social unitario e indivisible.

El poder en la República de Croacia se deriva del pueblo y pertenece al pueblo como una comunidad de ciudadanos libres e iguales.

El pueblo ejerce este poder a través de la elección de sus representantes y por medio de la toma directa de decisiones".

Constitución de Rumania de 1991. Art. 2 - Soberanía:

"(1) La soberanía nacional reside en el pueblo rumano, que la ejerce a través de sus órganos representativos y por referéndum.

(2) Ningún grupo o persona puede ejercer la soberanía en nombre propio".

Constitución de la República Checa de 1992. Art. 2:

“(1) El pueblo es la fuente de todo poder en el Estado; ejerce este poder a través de los órganos legislativo, ejecutivo y judicial.

(2) Una Ley Constitucional puede estipular cuando el pueblo ejerce el poder del Estado directamente.

(3) El poder del Estado sirve a todos los ciudadanos y puede ser ejercido sólo en los casos, dentro de los límites y por los medios especificados por la ley".

\section{Constitución de la Federación Rusa de 1993:}

\section{"Artículo 3.}

"1. El portador de la soberanía y única fuente de poder en la Federación Rusa es su pueblo multinacional.

2. El pueblo ejerce su poder directamente, asi como a través de los órganos de poder estatal y órganos de autogobierno local.

3. La expresión directa suprema del poder del pueblo son el referéndum y las elecciones libres.

4. Nadie puede arrogarse el poder en la Federación Rusa. Quien usurpe el poder o se arrogue atribuciones de poder será perseguido por la Ley Federal".

"Artículo 4.

1. La soberanía de la Federación Rusa es válida en todo su territorio. 
2. La Constitución de la Federación Rusa y otras leyes federales tienen supremacía en todo el territorio de la Federación Rusa.

3. La Federación Rusa asegura la integridad y la inviolabilidad de su territorio". Constitución de Ucrania de 1996. Art. 5:

"Ucrania es una república. El pueblo es la única fuente de poder en Ucrania. El pueblo ejerce el poder directamente y a través de los órganos de poder estatal y de autonomía local. El derecho para determinar y enmendar el orden constitucional en Ucrania pertenece solamente al pueblo y no puede ser usurpado por el Estado, sus órganos u oficiales. Nadie puede usurpar la autoridad del Estado".

Constitución de Polonia de 1997:

"Artículo 4: 1. El poder supremo de la República de Polonia será ejercido por la Nación. 2. La Nación ejercerá ese poder directamente o a través de sus representantes".

Otras Constituciones:

Constitución de la República Popular China de 1982:

"Artículo 2- Todo el Poder en la República Popular China pertenece al pueblo.

Los órganos por medio de los cuales el pueblo ejerce el Poder Estatal son la Asamblea Popular Nacional y las asambleas populares locales de los diversos niveles.

El pueblo administra los asuntos del Estado, las actividades económicas y culturales y los asuntos sociales por diversas vías y en distinta formas conforme a las estipulaciones de la ley".

Constitución de Egipto de 2014:

"Artículo 4: La soberanía es sólo del pueblo; es él quien la ejercita y la protege y es la fuente de todos los poderes. El pueblo es quien salvaguarda la unidad nacional basándose en los principios de la equidad, la justicia y la igualdad de oportunidades de acuerdo con lo especificado en la Constitución".

En todas las Constituciones referidas la soberanía se radica en el pueblo o en la nación. De ella emana el poder público que ejerce el pueblo directamente o por medio de sus representantes.

\section{LimitACiONES DE LA SOBERANÍA}

Como todo poder, el ejercicio de la soberanía reconoce limitaciones debidas, entre otros motivos, a que los Estados modernos - como apunta Zafra Va-Verde"están cada día más lejos de ser bloques aislados e impenetrables"; y así, se comunican y relacionan crecientemente sin importar las diferencias ideológicas, culturales o económicas que los separan. Entre estas limitaciones cabe destacar:

a) El ejercicio de la soberanía de los demás Estados y organizaciones supraestatales. (Arts. 1 y 2 de la Carta de la ONU). 
b) El respeto a la dignidad y a los derechos fundamentales propios de la persona humana, tanto de los reconocidos en el derecho interno como en los tratados internacionales actualmente vigentes y vinculantes. (Arts. $5^{\circ}$, inc. $2^{\circ}-\mathrm{CPR}$ ).

c) El respeto a los deberes y obligaciones válidamente contraídos con otros Estados. (Convención de Viena, de 23-V-1969, sobre el Derecho de los Tratados, art. 26).

d) El respeto a las delegaciones consentidas de soberanía, efectuadas a órganos internacionales depositarios de potestades públicas supraestatales. (Ej. D.T. $\left.24^{\mathrm{a}}-\mathrm{CPR}\right), \mathrm{y}$

e) El respeto a los principios que rigen la coexistencia de los Estados a nivel mundial, tales como los que enuncia el Preámbulo de la Carta de las Naciones Unidas, la preservación de la atmósfera y del medio ambiente y el desarrollo económico sustentable.

\section{Potestades COMPRENDIDAS EN LA SOBERANÍA Y ESENCIA DE ÉSTA}

Nos parece que en el desarrollo histórico del poder supremo del Estado se han ido incorporando o adquiriendo autonomía las potestades siguientes:

A.- El poder constituyente que está en la base de la soberanía.

B.- El poder de gobierno.

C.- El poder de administración.

D.- La potestad legislativa.

E.- La potestad jurisdiccional, y

F.- La potestad de control.

Su identificación con el ejercicio de la soberanía es tal que de ninguna de ellas es posible prescindir en un Estado de Derecho, particularmente en un Estado republicano y democrático como el nuestro.

Ahora bien, en el núcleo esencial de la soberanía se encuentra el poder constituyente, porque éste es la fuente originaria de todas las demás potestades; y, además, porque mientras éstas se ejercen por órganos cuya titularidad es temporal, el poder constituyente nace, se ejerce y permanece siempre radicado en el pueblo.

De allí que Georges Burdeau sostenga que "El carácter esencial de la soberanía es la posesión del Poder Constituyente” (ver nota 29).

\section{Segunda Parte: El Poder Constituyente}

\section{Origen histórico del Poder Constituyente}

La expresión "constituant” nace en Francia, en los albores de la Revolución y, concretamente, en la obra del abate Emmanuel Sieyés: Qué es el Tercer Estado, 
refiriéndose al poder que pertenece al pueblo para constituirse en la sociedad civil y política llamada Estado y para organizarlo y regularlo.

Esta expresión es comúnmente utilizada en los idiomas latinos; pero no existe -como una idea distinta de los poderes constituidos- en la lengua inglesa; toda vez que, desde su origen, el Parlamento británico ejerce indistintamente el poder de generar la ley y de dictar - por el mismo procedimiento- las normas constitucionales. Así, cuando los ingleses -y los norteamericanos inclusive- se refieren a este tipo de normas, usan la expresión: "constitutional".

Curiosamente, sin embargo, algunos autores han advertido que, en tanto la doctrina originaria del poder constituyente es francesa, su creación institucional es norteamericana y reconoce un origen inglés. En efecto, fue Oliver Cromwell quien, en 1653, promulgó una Constitución en cuyos artículos 19 y 34 se prohibía su derogación por una Ley del Parlamento.

En términos simples, el poder constituyente es aquel que se ejerce cuando se dicta una Constitución nueva o fundacional, cuando se reforma la existente o cuando se la sustituye por otra.

El ejercicio directo del poder constituyente por el pueblo es una curiosidad histórica actualmente desaparecida. Cuando hoy se habla del ejercicio democrático de este poder se recurre a la idea de la Asamblea Constituyente, modelo también creado en Francia, en 1789, bajo el nombre de Asamblea Nacional, conforme a las ideas del abate Sieyès expuestas en su libro ya referido, publicado en 1788 .

En esta Asamblea, junto con Sieyès, intervinieron diversos representantes perfilando el concepto del poder constituyente, así como la idea de los poderes constituidos y su relación de total dependencia de aquél. A estas intervenciones -notables por su valor doctrinal- nos referiremos en el párrafo siguiente.

Completando lo dicho precedentemente, el recordado Prof. Pablo Lucas Verdú explica que "La doctrina del poder constituyente procede de la organización eclesiástica inglesa y escocesa (Iglesia presbiteriana).

Efectivamente, la teoría del pacto (covenant) eclesiástico mediante el cual se obligan los creyentes para mantener sus convicciones y la Constitución eclesiástica es el origen de la doctrina del poder constituyente.

En el Agreement of the People de Cromwell, se mantiene la tesis que este pacto del pueblo está por encima del Parlamento puesto que fue acordado formalmente por el mismo pueblo.

En Nueva Inglaterra se aplicó esta concepción en las cartas constitucionales de Connecticut y Rhode Island mediante acuerdo unánime de las asambleas de los colonos. 
... Este procedimiento, seguido en Massachussets, se aplicó, también, en New Hamsphire (1783-1791) y, en definitiva, en la Constitución federal de 1787.

De los datos anteriores se desprende -como apunta Julius Hatschek-lo siguiente: 1) El poder constituyente corresponde al pueblo; 2) Este poder no puede ejercerse por representantes. Cuando sucede esto, las llamadas Conventions que elaboran la Constitución, sus miembros, son simples delegados del pueblo y éste tiene que ratificar el proyecto de Constitución.

El modelo americano del poder constituyente influyó en la Revolución francesa. Un cahier (documento que contenía las instrucciones de los electores a sus diputados, de la nobleza de Bugey) afirmaba que el poder supremo que consiste en el ejercicio de la volonté genérale no puede reservarse, limitarse o transmitirse porque se puede transmitir un poder, pero no la voluntad. Los Estados generales no son la Nación, sino su copia o imagen; no disponen de la soberanía, se les confía la facultad exclusiva de aprobar los impuestos y nuevas leyes, pero carecen de derecho de dictar aquellas leyes que sirven de fundamento del pacto constitucional. Esto último corresponde al pueblo (sans avoir le droit de prescrire celles qui servent de base au contrat social et á la forme du gouvernement, sans le consentement exprés de la nation).

Fueron el marqués de Condorcet y el abate Emmanuel Sieyés los teóricos del pouvoir constituant"20.

\section{El Poder Constituyente en la doctrina}

"El poder constituyente - decía Carl Schmitt- es la voluntad politica cuya fuerza o autoridad es capaz de adoptar la concreta decisión de conjunto sobre el modo y forma de la propia existencia política, determinando asi la existencia de la unidad política como un todo"21.

En términos más simples, entendemos el Poder Constituyente como el atributo esencial que tiene el pueblo para darse una Constitución original y para reformar la existente o sustituirla por otra.

Ahora bien, como manifestación esencial de la soberanía, el Poder Constituyente es indelegable.

Ya a mediados del siglo pasado el Prof. Carlos Sánchez Viamonte, basándose en el pensamiento del creador de la expresión francesa "pouvoir constituant", el abate Emmanuel Sieyès, señaló lo siguiente: "La separación entre el poder constituyente y

20 LuCAS Verdú (1983), pp. 581-582.

21 Sснмiтt (1982), p. 93. 
los poderes constituidos informan todos sus razonamientos relativos a la organización del gobierno, y no obstante haber caido esas expresiones en desuso progresivo a lo largo de los siglos XIX y XX, permanecen como un dogma fundamental inconmovible en todas las organizaciones jurídicas actuales".

Y añade, fundamentando su aserto: "En la sesión del día 2 de thermidor, año III, pronunció Sieyès las siguientes palabras: 'Una idea sana y útil fue establecida en 1788; es la división del poder constituyente y de los poderes constituidos. Ella será computada entre los descubrimientos que hacen dar un paso a la ciencia, y es debida a los franceses"'22.

El propio Sieyès, en el Capítulo XII de su Proyecto de Declaración, presentado el 21 de julio de 1789 a la Asamblea Nacional francesa, bajo el título "Poder constituyente y poderes constituidos", explica que "Del mismo modo que (los poderes) no pueden constituirse ellos mismos, no pueden tampoco cambiar su Constitución; (...) El poder constituyente puede todo en su género. No está sometido de antemano a una Constitución dada. La nación, que ejerce entonces el más grande, el más importante de sus poderes, debe hallarse, en esta función, libre de toda sujeción $y$ de toda otra forma que aquella que le plazca adoptar.

Pero no es necesario que los miembros de la sociedad ejerzan individualmente el poder constituyente. Pueden dar su confianza a representantes que se reunirán en asamblea para este solo objeto, sin poder ejercer ellos mismos ninguno de los poderes constituidos".

En su obra magistral, Sieyés había adelantado lo siguiente: Las leyes constitucionales "... son fundamentales no en el sentido de que puedan convertirse en independientes de la voluntad nacional, sino porque los cuerpos que existen y actúan por ellas no pueden tocarlas. En cada parte, la Constitución no es obra del poder constituido sino del poder constituyente. Ninguna especie de poder delegado puede cambiar nada en las condiciones de su delegación (...)"23.

Sánchez Viamonte, comenta al respecto: "La doctrina de Sieyès excluye toda posibilidad del ejercicio del poder constituyente por algunos de los poderes constituidos. Más que una separación de poderes, como se le podría considerar inadvertidamente, es una distinción fundamental respecto a su naturaleza". Y agrega de su cosecha el mismo autor: "El poder constituyente es un poder indelegable, aunque se encargue

22 Carré de Malberg (2000), pp. 1185 y ss. Este autor contradice el origen francés de la contraposición entre poder constituyente y poderes constituidos, y la atribuye a la Constitución Federal Norteamericana de 1787 y al testimonio de La Fayette: "Memoires", París, 1838, vol. IV, pp. 35 y ss.

23 SIEYÉs (1973), p. 86. 
su ejercicio a un cuerpo especial destinado a ese fin, y cuyos miembros son elegidos con ese unico objeto. En realidad, el pueblo no se desprende nunca de ese poder, y por eso debe reservarse la palabra definitiva, mediante el 'referéndum', que no aparece en la doctrina de Sieyès, pero que fue utilizado de un modo uniforme por los Estados de la Unión Norteamericana".

Por su parte, Carré de Malberg se plantea lo siguiente: "Se acaba de observar que, si bien no puede nadie, con anterioridad a la Constitución, invocar un derecho propiamente dicho al ejercicio del poder constituyente, en cambio, en el Estado ya constituido, este ejercicio corresponde a los órganos designados a dicho efecto por la Constitución vigente. - ¿Significa esto que la Constitución pueda conferir a cualquier autoridad la función constituyente? Y especialmente, ¿podría atribuirla a uno cualquiera de los órganos que ha destinado al ejercicio normal y habitual de las funciones del Estado?".

Después de analizar la objeción que presenta a esta hipótesis el principio de la soberanía nacional, el art. 3 de la Declaración de Derechos de 1789 y el Título III de la Constitución francesa de 1791, concluye que "Todo individuo o cuerpo que pretende ejercer una de las funciones de la soberanía debe haber recibido su potestad, para este efecto, de la nación misma, es decir, de un órgano superior que tiene jurídicamente el poder de formular sobre este punto la voluntad constituyente nacional. Asípues, el principio de la soberanía nacional implica lógicamente que el órgano constituyente ha de ser un órgano especial, diferente de los órganos constituidos".

Y, más adelante, especifica Carré de Malberg que: "-cualquiera que sea el nombre que se le dé: convención, asamblea de revisión, etc.- tiene por carácter esencial el ser una Constituyente, es decir, una asamblea especialmente llamada a ejercer el poder constituyente, formada por diputados que han sido elegidos por el pueblo para el cumplimiento de una labor constituyente $y$, por último, que no tienen otra función que la de efectuar la revisión para la que fue convocada, pues debe disolverse inmediatamente después de cumplida esta misión" 24 .

En la historia de la Asamblea Constituyente francesa de 1789, hallamos -además de la del abate Sieyès- tres intervenciones de miembros de la Asamblea Nacional, de las que se desprende la clara distinción entre poder constituyente y poderes constituidos, así como la interdicción impuesta a éstos de modificar la Constitución.

24 Carré de Malberg, ob. cit., pp. 1179-1183. 
Target presentó, en el Proyecto de Declaración de Derechos, la siguiente proposición: "'Art. 31. La Constitución es diferente de la legislación. La Constitución no puede ser fijada, cambiada o modificada sino por el poder constituyente, es decir, por la nación misma o por el cuerpo de representantes a quienes se lo ha encargado por un mandato especial. La legislación es ejercida por el poder constituido, es decir, por los diputados que la nación nombra en las épocas y según las formas que la Constitución ha fijado' (27 de julio de 1789, Archivo Parlamentario, t. VIII, pág. 289)".

El proyecto de Declaración de Mirabeau, contenía el siguiente: "Artículo $3^{\circ}$ : Todos los poderes a los cuales una nación se somete emanan de ella misma; ningún cuerpo, ningún individuo puede tener autoridad que no derive expresamente de ella. Toda asociación politica tiene el derecho inalienable de establecer, de modificar o de cambiar la Constitución, es decir, la forma de su gobierno, la distribución y los limites de los diferentes poderes que lo componen" (17 de agosto de 1789, Archivo Parlamentario, t. VIII, pág. 439).

Finalmente, Thouret, en su análisis de las ideas principales de la Declaración de Derechos, señalaba: "Los poderes públicos emanan todos del pueblo; ellos no pueden ni constituirse por si mismos ni cambiar la Constitución que han recibido. El poder constituyente reside esencialmente en la nación' (10 de agosto de 1789, Archivo Parlamentario, t. VIII, pág. 326)”.

Añade Sánchez Viamonte la cita de un interesante discurso del diputado Pétion en la Asamblea Nacional francesa de agosto de 1791: "Para evitar las confusiones que estas convenciones directas podrian producir, y a fin de que esta palabra no despierte en los espiritus ideas discordantes, en razón de las acepciones a menudo opuestas que le serán atribuidas, es necesario asignarle un sentido fijo y preciso. Yo llamaría, pues, convención a una asamblea investida por el pueblo de la autoridad necesaria para hacer y reformar su Constitución.

He oido distinguir las convenciones destinadas a hacer una Constitución de aquellas cuyo fin era modificar una Constitución ya hecha; esta distinción es un error y una pura sutileza. En el poder de cambiar y de reformar se encuentra necesariamente comprendido el de hacer o, para decirlo mejor, estos dos poderes son inseparables en su acción y en sus efectos. Por lo demás, esta distinción y todas las que podrian ser hechas respecto a las convenciones, no influyen nada sobre lo que tengo que decir; basta penetrarse bien del sentido que se da a esta palabra y que cada uno entienda que convención es una asamblea establecida para hacer o reformar una Constitución".

El mismo autor comenta al respecto: "Al estudiar la naturaleza del poder constituyente hemos distinguido las dos formas de su ejercicio: a) la etapa de primigeneidad, 
cuando no existe un orden jurídico anterior y hay que crearlo; b) la etapa de continuidad, cuando existe un orden jurídico anterior que se continúa, y hay que respetarlo. Pero en ambos casos se ejerce el poder constituyente que no cambia de naturaleza por el alcance cuantitativo que se le asigne. Sigue siendo poder constituyente lo mismo para reformar una Constitución en su totalidad que para cambiar una palabra, y por eso toda convención reunida para hacer una Constitución nueva o para reformar en todo o en parte una anterior es y será convención constituyente como lo sostiene Pètion en su discurso de $1791^{\prime 25}$.

A las citas históricas coetáneas a la promulgación de la Constitución norteamericana y a la Revolución Francesa, añadiremos la autorizada opinión de dos autores, universalmente conocidos, que escribieron en el S. XX sobre la "Teoría de la Constitución”: Carl Schmitt, que lo hizo en Alemania en 1928 y en España en 1934, y Karl Loewenstein que la publicó en Chicago en 1957 y en Tübingen en 1959, editándose en España en 1965.

Dice Carl Schmitt: "Es especialmente inexacto caracterizar como Poder constituyente, o pouvoir constituant, la facultad, atribuida y regulada sobre la base de una ley constitucional, de cambiar, es decir, de revisar determinaciones legal-constitucionales"26.

Añade, el mismo autor: "Límites de la facultad de reformar la Constitución.

"Cuando está regulado en ley constitucional el procedimiento de reforma de la Constitución, se funda con ello una competencia que no se explica por si misma. La competencia, regulada en ley constitucional, de los cuerpos legisladores para emitir leyes en las vías reguladas también por ley constitucional, es decir, la competencia legislativa ordinaria, no fundamenta por si sola ninguna competencia para reformar también prescripciones legal-constitucionales, que precisamente son base de la competencia misma. La competencia para reformar la Constitución no es una competencia normal en el sentido de un círculo de actividades regulado y delimitado. Reformar las leyes constitucionales no es una función normal del Estado, como dar leyes, resolver procesos, realizar actos administrativos, etc. Es una facultad extraordinaria"27.

\footnotetext{
25 Las citas que anteceden -exceptuando las de Bodino, Sieyés, Schmitt y Carré de Malberg- fueron tomadas del estudio de la voz "constituyente" desarrollado por el Dr. Carlos SÁnchez Viamonte que aparece en el Tomo IV de la Enciclopedia Jurídica OMEBA, Ed. Bibliográfica Argentina, B. Aires, 1967, pp. 11 a 69. 26 Sснмiтt (1982), p. 114.

27 Ibíd. Id., ob. cit., p. 118. Cuando Schmitt alude a normas "legal-constitucionales", se refiere a normas no reguladas en la Constitución, pero de tal importancia que se las ha revestido de requisitos especiales para su aprobación y modificación. Son similares a las leyes orgánicas constitucionales.
} 
Y concluye más adelante: "Los órganos competentes para acordar una ley de reforma de la Constitución no se convierten en titular o sujeto del Poder constituyente. Tampoco están comisionados para el ejercicio permanente de este Poder constituyente; por tanto, no son una especie de Asamblea nacional constituyente con dictadura soberana, que siempre subsiste en estado de latencia" 28.

Karl Loewenstein, por su parte, sostiene lo siguiente:

"El lugar del 'pouvoir constituant' - La cuestión central, sin embargo, de la reforma constitucional es: ¿dónde está su lugar político? $O$, visto sistemático-constitucionalmente, ¿cuáles son los órganos estatales autorizados, o en su caso obligados, a tomar la iniciativa de reforma y llevarla entonces adelante? La ideología del Estado constitucional democrático exige que la competencia para la reforma constitucional no sea el monopolio de un único detentador del poder, sino que debe de estar lo más distribuida que sea posible. Todos los detentadores legitimos del poder-gobierno, Parlamento y el pueblo organizado como electorado-deben poder participar en ella. A través de la máxima dispersión de esta participación, la reforma constitucional realizada adquiere el más amplio consenso y, con ello, la más elevada legitimidad. Si se permite expresar el problema de la situación del pouvoir constituant en forma de máxima, se podrá decir: soberano es aquel entre los detentadores del poder que decide sobre la reforma constitucional"29.

Ha dicho Georges Burdeau: "La idea de Derecho proviene de la consideración de un orden social deseable, dada una cierta representación del futuro. El soberano debe su titulo a que este orden social y este futuro no puede imponerse, sin su consentimiento, como fin de la reglamentación jurídica. De esta situación del soberano resulta que la soberanía es una fuerza que nace del conjunto de circunstancias históricas o nacionales en las que está la comunidad politica en un momento dado de su existencia. La soberanía tiende a ser la fuerza politica preponderante y su cualidad de no depender, en cuanto a su existencia, de ningún orden jurídico preestablecido la convierte en una noción exclusivamente política. No hay un estatuto del soberano como lo hay de los gobernantes; hay un hecho: el Poder de un hombre o de una colectividad que, dueños de las decisiones sobre el futuro del grupo, son, por eso, los amos de todo el ordenamiento jurídico.

Como el soberano está sobre todo estatuto constitucional, no está atado por él. Lo crea, pero no le debe nada. El carácter esencial de la soberanía es la posesión del

28 Ibíd. Id., p. 119.

29 Loewenstein (1983), p. 172. 
Poder constituyente. Con él, en efecto, el soberano detenta a la vez el dominio de la idea de Derecho que sirve de principio ordenador de la vida estatal y la elección de los gobernantes" 30 .

En fecha más reciente, el Prof. Díaz Ricci, refiriéndose al Poder Constituyente Democrático, sostiene lo siguiente: "Desde una perspectiva politica la Supremacía de la Constitución se encuentra solidariamente unida al Principio Democrático. En efecto, la superioridad de la Constitución se alimenta de su fundamento democrático: la soberanía popular. El pueblo es el sujeto a quien, en un Estado Democrático, se reconoce legitimación política para estructurar al estado, en consecuencia, establecer la Constitución y atribuirle carácter de ley suprema. Si el Pueblo es el titular de la Soberania - a través de los diversos medios de expresión- es a éste a quien pertenece el Poder Constituyente, es decir, el poder de organizar politicamente la sociedad y expresar esta decisión a través de un estatuto normativo al que deben someterse todas las instituciones y miembros, $y$, además, sólo podrá ser modificada o alterada por este mismo 'sujeto'.

La principal consecuencia de este principio está a la vista: por ser el Poder Constituyente popular el que crea las instituciones de la organización politica del Estado, éstas son poderes constituidos, 'criaturas' del Poder Constituyente y por lo tanto dependen de éste, se hallan subordinadas a éste, son inferiores en relación al poder constituyente popular. Por lo tanto, los órganos creados no pueden alterar la obra constituyente que guarda respecto de los órganos constituidos una posición de superioridad que los distingue y separa claramente.

El Principio Democrático exige la participación del Pueblo en la determinación de la organización política, en consecuencia, lo que éste resuelva sólo podrá ser cambiado por el mismo sujeto, o sea, por el propio pueblo. Por lo tanto, los actos de órganos estatales y las normas que en lo sucesivo se dicten por los sujetos habilitados al efecto, no pueden afectar lo que el pueblo haya resuelto y, aún más, debe armonizar su acción y conformar sus normas a lo establecido en la Constitución simplemente por haberlo asi dispuesto la Voluntad Popular. En resumen, siendo ésta soberana, las decisiones que adopte a través de la Constitución son supremas, no reconoce sujeto $u$ orden normativo superior al Pueblo y su Constitución"31.

Desde la misma perspectiva, el Prof. Miguel Carbonell sostiene: "Desde luego, los vínculos entre democracia y reforma constitucional son insoslayables. De

30 Burdeau (1981), p. 46.

31 Díaz (2001), pp. 895 y s. 
hecho la posibilidad de que una Constitución sea reformada es una de las mejores y más acabadas expresiones de su propia legitimidad (es decir, de su capacidad para reclamar obediencia voluntaria para sus mandatos por parte de los sujetos a los que pretenden regular): en tanto puede ser cambiada, todos deben en principio obedecerla y en caso de discrepar de sus prescripciones, deben intentar el cambio por la vía constitucional exclusivamente (la de la reforma), sin que sea posible apelar a ningún tipo de traba jurídica como legitimación para salir del orden constitucionalmente establecido.

... Que la Constitución tenga que disponer de un procedimiento para su propia reforma parece ser algo que estuvo fuera de dudas tanto en los procesos revolucionarios franceses como en el americano, de los cuales, dicho sea de paso, el constitucionalismo actual es, como se sabe, directo heredero. El artículo 28 de la Constitución francesa de 1793 ya disponía que 'Un pueblo tiene siempre el derecho a revisar, reformar y cambiar su Constitución. Una generación no puede someter a sus leyes a las generaciones futuras' y en el mismo sentido se expresaron Jefferson y Paine.

¿Qué órgano debe hacer las reformas constitucionales?

Una primera evidencia es que, si se acepta que el poder constituyente originario es un poder distinto al resto de poderes constituidos, conviene que esa diferencia se proyecte, cuando menos, en la distinta integración o funcionamiento de uno y otros; es decir, que ningún poder constituido pueda identificarse, en cuanto 'órgano', con el poder revisor de la Constitución.

En este sentido, Loewenstein afirma que 'La ideología del Estado constitucional democrático exige que la competencia para la reforma constitucional no sea el monopolio de un unico detentador del poder, sino que debe estar lo más distribuida que sea posible. ¿Distribuida a quiénes o entre quiénes? El mismo autor responde diciendo que deben participar en ella el gobierno, el Parlamento y el pueblo organizado como electorado"32.

\section{El PODER CONSTITUYENTE INSTITUIDO O DERIVADO:}

UN FRAUDE A LA ESENCIA DE LA SOBERANÍA

Se ha dado en llamar "poder constituyente instituido" o "poder constituyente derivado" a la potestad que se atribuye a un órgano mixto -generalmente integrado por los órganos encargados de elaborar la legislación- para modificar,

32 Carbonell, pp. 851 y s. 
total o parcialmente, la Carta Fundamental, con la sola sujeción a requisitos procedimentales más exigentes que los requeridos para la aprobación de las leyes.

De la fundamentación que hemos expuesto, tanto de la soberanía como del poder constituyente, de su origen, su naturaleza y sus caracteres esenciales, no cabe sino concluir que la creación abstrusa de esta potestad artificiosa, sustitutiva del verdadero poder constituyente, es un fraude al legítimo ejercicio de la soberanía que sólo corresponde al pueblo.

En efecto, no puede conferirse a poderes constituidos, que derivan su origen, su función y su competencia del poder constituyente, la potestad esencial de éste, por la misma razón que la creatura no puede reemplazar a su creador.

No puede ningún órgano del Estado ser delegatario de una potestad indelegable.

El ejercicio del poder constituyente por poderes constituidos conlleva la usurpación de una potestad que pertenece exclusivamente al pueblo; y cuyo ejercicio, si no puede ser limitado, mucho menos puede ser sustituido por aquéllos.

Ahora bien, esta usurpación fraudulenta del ejercicio de la potestad esencial de la soberanía conduce a la comisión de graves errores en la creación y en la modificación de las atribuciones de órganos esenciales para nuestra existencia republicana y democrática y el riesgo -aún más grave- del uso abusivo de este poder usurpado al pueblo, como lo evidencian algunos ejemplos, a saber:

- En Chile, son órganos de poder supremo el Tribunal Constitucional y la Contraloría General de la República que ejercen, dentro de sus competencias respectivas, parte de la soberanía que sólo el pueblo pudo conferirles al crearlos. Sin embargo, estos órganos fueron creados mediante reformas constitucionales, es decir, mediante la actuación de dos órganos de poder constituidos: el Presidente de la República y el Congreso Nacional.

- ¿De dónde obtuvieron estos órganos de poder constituido la autoridad necesaria para crear órganos constitucionales nuevos? Al hacerlo, usurparon al pueblo el poder constituyente que sólo a éste corresponde.

- ¿De qué fuente obtuvieron los poderes constituidos señalados las competencias soberanas de poder público que atribuyeron gratuitamente a los nuevos órganos creados por ellos?

En la Ley de Reforma Constitucional No 20.050 del año 2005 se encuentran varios ejemplos de la misma grave anomalía:

- ¿Cómo pudo el Presidente de la República y el Congreso Nacional modificar más de la mitad de la Constitución vigente, es decir, ejercer el poder constituyente que sólo pertenece al pueblo? 
- ¿Cómo pudo la Cámara de Diputados atribuirse el poder de contribuir a la designación de dos miembros del Tribunal Constitucional, sin apropiarse del poder constituyente que no le pertenece?

- ¿Cómo pudieron, el P. de la R. y el Congreso, modificar sustancialmente la composición, la forma de nombramiento de sus miembros y las atribuciones esenciales del Tribunal Constitucional sin hallarse radicado el poder constituyente en estos dos poderes constituidos?

- Un acto de ilusionismo sorprendente ha tenido lugar a comienzos del presente año: El 15-II-2014 se dictó la Ley de Reforma Constitucional No 20.725, la cual suprime el número de 120 diputados que contemplaba el art. 47 de la Constitución, abriendo la posibilidad de que la Cámara de Diputados quede integrada por 150 miembros o por un número aún mayor según lo determine la respectiva Ley Orgánica Constitucional sobre Votaciones Populares y Escrutinios. Como la Constitución nada dice acerca del número de miembros que componen el Senado, éste podrá ser determinado por la misma Ley Orgánica Constitucional, pudiendo aumentarse el actual número de 38 Senadores a 50 o a otro número que se apruebe.

- ¿Cómo es posible que el órgano legislativo por excelencia pueda aumentar el número de sus miembros por sí mismo, bastándole el acuerdo del P. de la R., en circunstancias que ambos órganos son "poderes constituidos" cuya generación, modificación o supresión dependen exclusivamente del ejercicio del poder constituyente que sólo corresponde al pueblo? No cabe duda que la modificación de un órgano fundamental del Estado como es el Congreso Nacional, de sus atribuciones y de la remuneración de sus miembros, es un ejercicio de soberanía que no corresponde al mismo órgano constituido que así la ejercita indebidamente.

La más sorprendente apropiación de la soberanía popular y de su principal manifestación que es el ejercicio de poder constituyente, la encontramos en la Disposición Transitoria No 24 de la Constitución que autoriza al Estado de Chile para reconocer la jurisdicción de la Corte Penal Internacional en los términos del Tratado de Roma de 17-VII-1998, aprobado por la Conferencia Diplomática de Plenipotenciarios de las Naciones Unidas sobre la creación de dicha Corte.

No obstante que la jurisdicción reconocida a la Corte Penal Internacional es subsidiaria de la de los tribunales chilenos, dicho reconocimiento implica una delegación de soberanía en un tribunal supranacional que se sobrepone a la jurisdicción interna de Chile y -por ende- requiere de una reforma constitucional previa y expresa en los términos precisos de la sentencia de inconstitucionalidad dictada por el Tribunal Constitucional en el rol No 346, con fecha 8 de abril 
de 2002; no bastando una mera disposición transitoria que autoriza al Estado para practicar dicho reconocimiento; materia que -en todo caso- constituye un ejercicio del poder constituyente que pertenece exclusivamente al pueblo de Chile.

\section{Conclusiones}

De lo investigado y transcrito podemos concluir:

$1^{\circ}$ El poder constituyente es de la esencia de la soberanía. No se agota ni se suspende luego del acto fundacional del Estado constituido, sino que permanece radicado en el pueblo durante toda la existencia de aquél, poniéndose en ejercicio cada vez que la Constitución deba ser reformada o sustituida.

$2^{\circ}$ No cabe diferenciar cualitativamente el ejercicio del poder constituyente dirigido a cambiar la Constitución de aquél encaminado a reformarla parcialmente. Ambas operaciones sólo presentan una diferencia cuantitativa, pero ambas participan de la misma naturaleza.

$3^{\circ}$ El poder constituyente no puede ejercitarse por todo el pueblo por motivos de imposibilidad física y de madurez cívica. Por tales razones su ejercicio corresponde a la ciudadanía, es decir, al Cuerpo Electoral de la nación.

4o Atendido el número multitudinario de ciudadanos, la única fórmula democrática, igualitaria y universalmente participativa de todo el pueblo que parece procedente y razonable, consiste en que la ciudadanía comisione a una Asamblea Constituyente -compuesta por un número prudencial y pluralista de ciudadanos- para estudiar, redactar y proponer un Proyecto de nueva Constitución o de reforma constitucional según el caso.

Este cometido no significa desprenderse o delegar el poder constituyente, ya que el Cuerpo Electoral lo mantiene hasta el momento de ejercitarlo efectivamente en el referéndum al que el o los Proyectos alternativos de reforma que proponga dicha Asamblea sean sometidos a su soberana decisión.

$5^{\circ}$ Es absolutamente inaceptable, por ser improcedente, la delegación del poder constituyente en uno o más poderes constituidos. Primero: porque cada uno de éstos tiene sellada su competencia dentro de las limitadas funciones propias del órgano respectivo. Segundo: porque al modificar en cualquier forma la Constitución, el órgano constituido estaría socavando la fuente misma del poder que le ha creado y de la competencia que le ha sido conferida. Tercero: porque un principio básico del poder constituyente consiste en ser indelegable. La Constitución no puede privar al pueblo soberano del ejercicio de la soberanía 
de que es titular, atribuyendo su potestad esencial a órganos subalternos como son los poderes constituidos.

\section{Tercera Parte: Una nueva Constitución para Chile \\ 1. LA RACIONALIDAD JURÍDICO-POLÍTICA QUE JUSTIFICA UNA AUTÉNTICA CONSTITUCIÓN DEMOCRÁTICA}

A la sola mención de este tema, revive un temor tan antiguo como la humanidad: el horror al vacío; el freno que impedía a los antiguos navegantes adentrarse en el mar para no caer en el abismo.

Este temor se alimenta de dos riesgos imaginarios:

- Creer que una nueva Constitución significaría eliminar de una plumada y en su integridad la Carta Fundamental de 1980; y

- Suponer que su resultado sería una Constitución neoliberal -tributaria del modelo norteamericano- si en la asamblea constituyente que se elija triunfa la Derecha; o una Constitución socialista -tributaria del modelo chino- si triunfa la Izquierda.

Nada más absurdo que estos temores infundados.

La nueva Constitución será el resultado de un consenso adoptado en forma democrática por el pueblo chileno. La democracia se funda en la confianza en la sensatez del pueblo en su conjunto. Y el pueblo chileno, no obstante su enorme diversidad, siempre ha dado muestras de sensatez política.

Por lo mismo y, además, porque ninguna tendencia ideológica cuenta con la mayoría necesaria para imponerse, la posibilidad de una Constitución ideológica debe quedar descartada.

También -creo yo- debe descartarse la alternativa de prescindir absolutamente de la Constitución que nos rige. Lo que objetamos es su ilegitimidad de origen y los enclaves autoritarios contenidos en ella que mantienen estancado nuestro desarrollo democrático. Pero no cabe duda que sería positivo y deseable rescatar de ella los valores que forman parte de nuestra cultura política occidental -la dignidad humana, la libertad, la vocación igualitaria, la justicia, el pluralismo, los derechos fundamentales, la democracia-; los principios que han regido siempre nuestro ordenamiento jurídico-político -la legalidad, la interdicción de toda arbitrariedad, la jerarquía normativa y la supremacía de la Constitución, la participación ciudadana, la seguridad jurídica, la probidad, la publicidad de las normas y de la actividad pública, la responsabilidad y la tutela judicial de los derechos- por 
mencionar sólo las más evidentes; también cabría preservar nuestra valiosa institucionalidad política, como el régimen presidencial, el Congreso Nacional, el Poder Judicial, el Tribunal Constitucional, la Justicia Electoral, la Contraloría General de la República, las Fuerzas Armadas y de Orden y Seguridad Pública; sin perjuicio de los ajustes y reformas susceptibles de mejorar su desempeño.

En resumen, siendo así: a) que las Constituciones más perdurables -que son las de 1833 y de 1925 que nos rigieron durante 140 años- radicaron la soberanía en la nación y, la actualmente vigente, la hace residir en la nación entregando su ejercicio al pueblo y a las autoridades que la Constitución establece;

b) que durante dos siglos de historia constitucional -1811-2014- jamás el pueblo chileno ha ejercido la potestad esencial de la soberanía: el poder constituyente ${ }^{33}$;

c) que parece vergonzoso que después de un cuarto de siglo de recuperada la democracia, aceptemos seguir siendo regidos por la Carta ilegítima dictada por un gobierno de facto;

d) que tampoco se puede parchar un traje confeccionado a su medida por la dictadura militar para vestir a nuestra democracia, $y$

e) que la Carta Fundamental vigente -además del lastre de su ilegitimidadalberga numerosas falencias -de orden interno e internacional-, así como restricciones antidemocráticas que la nueva Constitución debe subsanar y corregir. Nos parece llegada la hora de restituir al pueblo soberano el ejercicio del poder constituyente y, con ello, la decisión de su propio destino. El ejercicio de este poder es de la esencia de una Constitución democrática.

\section{LA EVOLUCiÓN DE LA CONCIENCIA CÍVICO-POLÍTICA CHILENA}

La nueva Constitución no sólo pretende el ejercicio por nuestro pueblo del poder constituyente que nunca se le ha permitido ejercer. Y no sólo ella debe rescatar los valores, los principios y la institucionalidad elaborada a través de dos siglos de historia. También debe recoger la rica evolución constitucional chilena, no la que yace en la letra de los textos, sino la que sigue la línea ascendente de

33 Dicen algunos historiadores que esto ocurrió con la Constitución de 1828. La verdad es que se eligió a 98 diputados que formaron el "Congreso Constituyente". Pero éste delegó sus funciones en una Comisión de 5 diputados, cuyo Informe fue aprobado por el Congreso. Se promulgó el 8-VIII-1828 y el 18-IX-1828 "se juró por los pueblos", sin que éstos tuvieran en ella mayor participación. 
nuestra conciencia cívico-política democrática que ha sido evaluada como una de las de más alto grado de desarrollo en el mundo ${ }^{34}$.

Sólo para dar una idea de lo que señalamos, considérese la evolución del sufragio -masculino, censitario y restrictivo en la Carta de 1833- a un sufragio universal -que también se otorga a los extranjeros, depurado del estigma del cohecho mediante la cédula oficial- que existe en la actualidad. Considérese la evolución de los partidos políticos y la vigencia actual del pluralismo. Apréciese la condición de súbditos que tuvieron las personas frente al Estado en las antiguas Constituciones y su actual relación en que "El Estado está al servicio de la persona humana" (art. $1^{\circ}$ - CPR). Adviértase la proclamación de la dignidad humana que no sólo es la raíz de la libertad e igualdad de las personas, sino también la fuente y medida de los derechos fundamentales; la dignidad se ha encarnado con tanta fuerza en la conciencia colectiva que los sectores vulnerados se manifiestan y reclaman sus derechos por respeto a su dignidad. También ha evolucionado notablemente el amparo a los cuerpos intermedios y a su autonomía y las formas y medios de participación igualitaria de las personas en la vida nacional.

A esta nueva conciencia constitucional que hoy se respira, la nueva Constitución debiera incorporar las legítimas aspiraciones que alimentan las esperanzas de los sectores más vulnerables de la comunidad nacional.

Hablamos -a nivel nacional- de dar una mayor concreción a los derechos sociales -salud, educación, vivienda, preservación del medioambiente-; a nivel regional, promover enérgicamente la descentralización administrativa y un reparto equitativo de los recursos públicos entre las regiones; y, a nivel internacional, regular el derecho internacional como fuente jurídica y su valor jerárquico; y promover la integración progresiva suramericana y latinoamericana y la delegación de competencias encaminadas a la unión soberana de los Estados de este subcontinente.

\section{Generación de una Constitución Democrática}

En esta materia se advierten los mayores tropiezos.

Hay quienes promueven el llamado a una Asamblea Constituyente que sería el primer paso para elaborar la nueva Constitución.

Pero hay quienes advierten, con razón, que tal asamblea no está contemplada en el Capítulo XV de la Constitución.

\footnotetext{
34 Ver: Sergio Gutiérrez Olivos en su Discurso de Recepción de Francisco Bulnes Sanfuentes en la Academia Chilena de Ciencias Sociales, Ed. Universitaria, Stgo., 1986, pp. 35-36.
} 
Y es claro que no lo está, pues dicho Capítulo regula la "Reforma de la Constitución”, es decir, la modificación de alguna de sus normas. Ninguna Constitución se dicta para ser sustituida; y por eso sólo se contempla en ellas su modificación o reforma. Así se advierte claramente de la lectura del inciso $2^{\circ}$ del art. 127, que distingue los distintos quorum de aprobación que requiere dicha reforma, según recaiga en determinados capítulos de la Carta o afecte a alguno de los demás. Esta distinción entre capítulos de quorum reforzado y otros de quorum ordinario, revela claramente que la "Reforma" se refiere a modificaciones parciales de la Constitución.

Pero cabe la siguiente observación descalificatoria de la legitimidad de este capítulo. En él se está atribuyendo el Poder Constituyente a dos poderes constituidos como son el Presidente de la República y el Congreso Nacional; siendo así que el poder constituyente es uno solo -sea para modificar o para sustituir la Constitución- y que ese poder es indelegable y menos delegable aún, si ello cabe, en dos poderes constituidos.

Nuestra actual Presidenta de la República ha propiciado en su Programa una nueva Constitución, pero dictada "por cauces institucionales".

Pues bien, vamos a suponer -como una mera hipótesis- que la Constitución de 1980 fuera legítima y que hubiera que ceñirse a sus normas para proyectar una nueva.

Puestos en ese trance, jamás recurriríamos al Capítulo XV que sólo trata de la "Reforma de la Constitución". Vale la pena recordar que la voz "Reforma" significa: "Aquello que se propone, proyecta o ejecuta como innovación o mejora en algo". Como una nueva Constitución no se proyecta para innovar o mejorar la actual sino para sustituirla, el Cap. XV no sirve para tal propósito.

En cambio, si repasamos las "Bases de la Institucionalidad", (Cap. I-CPR.) descubriremos el pilar del art. $5^{\circ}$ que reza: "La soberanía reside esencialmente en la Nación. Su ejercicio se realiza por el pueblo a través del plebiscito y de elecciones periódicas y, también, por las autoridades que esta Constitución establece. Ningún sector del pueblo ni individuo alguno puede atribuirse su ejercicio".

Pues bien, si el ejercicio de la soberanía se realiza por el pueblo y una de sus formas es a través del plebiscito, ninguna norma de rango constitucional se opone a que el Presidente, en uso de su iniciativa legal, envíe al Congreso un Proyecto de Ley fundado en la necesidad de regular las bases esenciales de la institucionalidad del plebiscito -como instrumento del ejercicio de la soberanía por el pueblo-según está previsto en el art. 50 de la Constitución y en conformidad al art. 63 № 20 de la misma. Un artículo transitorio de dicho Proyecto podría regular el primer 
plebiscito, destinado a que la ciudadanía se pronuncie acerca de la elaboración de una nueva Constitución o la permanencia de la que está vigente.

Dos observaciones podrían formularse a la factibilidad de esta hipótesis:

A) Que el art. 15-CPR., en su inciso $2^{\circ}$ prescribe que "Sólo podrá convocarse a votación popular para las elecciones y plebiscitos expresamente previstos en esta Constitución”. Pues bien, el plebiscito está expresamente previsto en el art. 50 -CPR, entre las "Bases de la Institucionalidad".

B) Que el Presidente puede "Convocar a plebiscito en los casos del art. 128" (Reforma de la Constitución). Esta es una "atribución especial" del Presidente, contenida en el No 4 del art. 32 que establece esta facultad. Lo que no obsta a la iniciativa legal que tiene el Presidente para, mediante un Mensaje al Congreso, proponer un proyecto de ley regulatorio de las bases de una institución política prevista en la propia Constitución, como es el plebiscito.

De esta manera, tanto el plebiscito como ejercicio de la soberanía, como la asamblea constituyente, están "dentro de los cauces institucionales".

A este respecto, el Prof. Francisco Zúñiga ha expresado: "En las coordenadas del poder constituyente originario democrático, la asamblea constituyente, congreso constituyente, junto al referéndum constituyente, tienen un lugar principal como técnicas o mecanismos de procedimientos democráticos a través de los cuales encauzar la potestad constituyente y traducir éste en decisiones e instrumento de gobierno. Tales procedimientos y el sistema de normas electorales y de competencia (convocatoria a elecciones, sistema electoral para elección de asambleistas o congresistas constituyentes, organización y funcionamiento de la asamblea constituyente, ulterior ratificación vía referéndum, entre otras materias) que permitan el ejercicio de la potestad constituyente naturalmente no se somete al reparto de potestades normativas que hace la Constitución de 1980/2005. El poder constituyente originario democrático se dará sus reglas, no para imponer una 'dictadura de las mayorias' sino para lograr los consensos necesarios de un pacto político necesario para alumbrar una nueva Constitución"35.

Dos reflexiones para terminar:

Se sabe que - por lo general- las cosas más valiosas sólo se aprecian cabalmente cuando se pierden. No he encontrado una mejor expresión del sentimiento de la soberanía perdida que en este discurso de un jefe tribal africano, al concluir el rito de pasaje a la adultez de un grupo de adolescentes.

35 ZÚNIGG (2012). 
Dijo Meligqili: "He ahi a nuestros hijos. Jóvenes, sanos y hermosos, la flor y nata de la tribu xhosa, el orgullo de nuestra nación. Acabamos de circuncidarles siguiendo un ritual que les promete la hombría, pero estoy aqui para decirles que no es más que una promesa vacía e ilusoria. Es una promesa que jamás podrá ser cumplida, porque nosotros los xhosas, y todos los sudafricanos negros, somos un pueblo conquistado. Somos esclavos en nuestro propio pais. Somos arrendatarios de nuestra propia tierra. Carecemos de fuerza, de poder, de control sobre nuestro propio destino en la tierra que nos vio nacer. Se irán a ciudades donde vivirán en chamizos y beberán alcohol barato, $y$ todo porque carecemos de tierras que ofrecerles donde puedan prosperar y multiplicarse. Toserán hasta escupir los pulmones en las entrañas de las minas del hombre blanco, destruyendo su salud, sin ver jamás el sol, para que el blanco pueda vivir una vida de prosperidad sin precedentes. Entre estos jóvenes hay jefes que jamás gobernarán, porque carecemos de poder para gobernarnos a nosotros mismos; soldados que jamás combatirán, porque carecemos de armas con las que luchar; maestros que jamás enseñarán porque no tenemos lugar para que estudien. La capacidad, la inteligencia, el potencial de estos jóvenes se desperdiciarán en su lucha por malvivir realizando las tareas más simples y rutinarias en beneficio del hombre blanco. Estos dones son hoy en día lo mismo que nada, ya que no podemos darles el mayor de los dones, la libertad y la independencia. Sé muy bien que Qamata (Dios africano) lo ve todo y nunca duerme, pero sospecho que últimamente está dormido. Si así fuera, cuanto antes me llegue la muerte mejor, ya que asi podré presentarme ante él, despertarle y decirle que los niños de Ngubengcuka, la flor y nata de la nación Xhosa, están muriendo"36.

Y así como se puede añorar el ejercicio de la soberanía perdida-como lo revela el crudo discurso del jefe tribal africano que escuchó Mandela en su mocedad-, así también se puede carecer de la vivencia de la soberanía por no haber ejercido jamás su función primordial el pueblo que se dice soberano; esto es, por no haber practicado nunca el ejercicio cabal del poder constituyente, como ha ocurrido entre nosotros en todo el desarrollo de nuestra historia.

En efecto, muchas veces la voluntad popular fue sustituida por una Comisión a la que se atribuyó ese poder, o a poderes constituidos teniendo como resultado las Cartas que se dictaron a partir de 1818. Otras veces, el poder constituyente fue usurpado por un gobierno dictatorial que otorgó una Carta hecha a su medida, como sucedió con la Constitución de 1980.

36 Mandela (2014), p. 41. 
Finalmente, todas las reformas constitucionales votadas sin la participación del pueblo -único depositario auténtico del poder constituyente-adolecen de idéntica ilegitimidad. Somos ciudadanos de un pueblo castrado del primer atributo de la soberanía: el de decidir nosotros mismos lo que queremos ser.

\section{BiBLIOGRAFÍA CITADA}

BAUdin, Louis (1997): El Imperio Socialista de los Incas, 8a . ed. (Lima, Editorial Amaru).

Battaglia, Felice (1966): Estudios de Teoría del Estado (Bolonia, Real Colegio de España).

Biblia: Éxodo, Capítulos 7 al 12.

Bodin, Jean (1992): Los Seis Libros de la República (traducc. Gaspar de Añastro Isunza, Madrid, Centro de Estudios Constitucionales).

Burdeau, Georges (1981): Derecho Constitucional e Instituciones Politicas (Madrid, Ed. Nacional).

Carbonell, Miguel: "Sobre la Reforma Constitucional y sus funciones", en Estudios de Teoría del Estado y Derecho Constitucional en Honor de Pablo Lucas Verdú. Tomo II.

Carré de Malberg, Raymond (2000): Teoría General del Estado. 2a Edición (México, F.C.E.).

De Jouvenel, Bertrand (1964): El Poder (Madrid, Editorial Nacional).

Díaz Ricci, Sergio (2001): “Supremacía de la Constitución”, en Estudios de Teoría del Estado y Derecho Constitucional en Honor de Pablo Lucas Verdú (U. Complutense de Madrid, y UNAM, México). Tomo II.

FischBACH, Oscar Georg: Teoría General del Estado (Barcelona, Editorial Labor).

García Cotarelo, Ramón (1983): Introducción a la Teoría del Estado. 2a Edición (Barcelona, Ed. Teide).

González Casanova, José Antonio (1983): Teoría del Estado y Derecho Constitucional, 2a reedición (Barcelona, Editorial Vicens-Vives).

Gutiérrez Olivos, Sergio (1986): Discurso de Recepción de Francisco Bulnes Sanfuentes en la Academia Chilena de Ciencias Sociales (Santiago, Editorial Universitaria).

Hauriou, André; Gicquel, Jean y Gélard, P. (1980): Derecho Constitucional e Instituciones Políticas (traducc. José A. González Casanova, Barcelona, Editorial Ariel).

Heller, Hermann (1983): Teoría del Estado. 9ª reimpresión en español (México, F.C.E.). 
Hobbes, Thomas (1980): Leviatán, 2a Edición (México, F.C.E.).

JellineK, Georg (1978): Teoría General del Estado (Buenos Aires, Editorial Albatros).

KeLSEn, Hans (1983): Teoría General del Derecho y del Estado (México, UNAM).

Mandela, Nelson (2014): El Largo Camino Hacia la Libertad. 4a. edición (Santiago de Chile, Editorial Aguilar).

Loewenstein, Karl (1983): Teoría de la Constitución (Barcelona, Editorial Ariel).

Lucas Verdú, Pablo (1983): Curso de Derecho Político. 3a. Edición (Madrid, Tecnos), vol. II.

Pérez Serrano, Nicolás (1976): Tratado de Derecho Politico (Madrid, Editorial Civitas).

Pontificia Universidad Católica de Chile (1989): "Razón y Fuerza de la Constitución de 1980", en XIX Jornadas Chilenas de Derecho Público, Revista Chilena de Derecho. Vol. 16 (No 2), pp. 325 y ss.

Sánchez Viamonte, Carlos (1967): "constituyente" en Enciclopedia Jurídica OMEBA (Buenos Aires, Editorial Bibliográfica). Tomo IV.

Schmitt, Carl (1982): Teoría de la Constitución (Madrid, Edición Alianza).

SIEYÉS, Emmanuel (1973): ¿Qué es el Tercer Estado? (Barcelona, Edición Aguilar S.A.).

ZúNiga Urbina, Francisco (2012): "Nueva Constitución y Operación Constituyente", en XLII Jornadas Chilenas de Derecho Público Pontificia Universidad Católica de Valparaíso. 